(C) Springer International Publishing AG, part of Springer Nature 2018

Amy Cutter-Mackenzie,

Karen Malone

and

Elisabeth Barratt Hacking

Research Handbook on Childhoodnature

Springer International Handbooks of Education

10.1007/978-3-319-51949-4_25-1

To cite:

Vladimirova A., \& Rautio P. (2018). Unplanning research with a curious practice methodology: Emergence of childrenforest in the context of Finland. In A. Cutter-Mackenzie, K. Malone, E. Barratt Hacking (Eds.),

Research handbook on childhoodnature. Cham, Switzerland: Springer.

\title{
Unplanning Research with a Curious Practice Methodology: Emergence of Childrenforest in the Context of Finland
}

Anna Vladimirova ${ }^{1}$ and Pauliina Rautio ${ }^{2}$

(1)University of Oulu, Oulu, Finland

(2)Faculty of Education, University of Oulu, Oulu, Finland

Anna Vladimirova (Corresponding author)

Email: avladimi@student.oulu.fi

Pauliina Rautio

Email: pauliina.rautio@oulu.fi

\begin{abstract}
This chapter explores the notion of curious practice and the methodology of its application in the context of primary school education in Finland. The concept of curious practice encourages us researchers and educators - to ask "How does curious practice help us to address children's relations to forests beyond the child (in) nature dualism?" Curious practice challenges the existing environmental education methodologies employed in recent years that draw heavily on research planning, the child's representation of nature, and the results of a completed study. Despret's (Domesticating practices: The case of Arabian Babblers. In G. Marvin and S. McHugh (Eds.), Routledge handbook of human-animal studies (pp. 23-38). New York: Routledge, 2014) approach of curious practice encourages researchers to unplan and make themselves available to the yet unknown, for every single encounter with the other is a mixture of unpredictability, the researcher's attentiveness, and imagination. The rationale behind curious practice is in learning more about what is seen and heard via questioning the encounters that accept various absences of a preconceived framework of research. As a necessary complement to such a methodology, the chapter also presents a
\end{abstract}


semiotic approach, employed by Eduardo Kohn ( How forests think: Toward an anthropology beyond the human. Berkeley: University of California Press, 2013), to inform the method of studying the logic of the world beyond human symbolism. The data used reveal an interdependency of children and forests that will be referred to as childrenforest in that it continuously generates a network of signs which adults and children themselves often are unable to access or represent. These present absences found in curious practice are crucial for our understanding of what we have overlooked while claiming that the other is known. With that, however, childrenforest cannot be fully grasped. Andrew Pickering's ( Natures Sciences Sociétés, 1(21), 77-83, 2013) notion of islands of stability is utilized to elaborate the ways that childrenforests signal the presence of the seemingly stable configurations of their dynamic becoming. The chapter concludes with a short discussion of the potential areas of curious practice application beyond the ethological and childhood research.

Keywords Curious practice - Despret - Islands of stability - Semiosis of childrenforest - Reals Unplanning

\section{Introduction}

The concept of childhoodnature is fluid, and so there are numerous ways to formulate its practices in research, or pedagogy, or policy. The methodological inquiry discussed in our chapter focused on research aims to clarify one key understanding, simultaneously relating this understanding to other research practices of children and nature. To do this, we discuss a study conducted in the context of primary school education in Finland. We introduce an in situ development of curious practice as a methodology to explore what we will call childrenforest. "Curious practice" is a theoretical notion coined by Donna Haraway ( 2015) and inspired by Vinciane Despret (2014). At the heart of Despret's ethological work lies the demand for scientific and philosophical inquiry into the relationships of people and animals, observer and observed, and researcher and researched in ways that challenge rather than rely on these binary positions.

The research context of the empirical study is a nature school to which local school classes make field trips in a northern city in Finland. The research involved 5 weeks of full-time work between February and March 2017. The human participants were the nature school teacher Niina, 438 children from first to fourth grade (i.e., 7-10 years old), class teachers, their assistants, and the researchers. The forest visited by the school children and adults comprised a diverse collection of more-thanhuman participants, emerging differently with each visiting class. And so, the unit of analysis was conceived as childrenforest - a concept to be developed in what follows.

The methodological question discussed in this chapter is how does curious practice help us to address children's relations to forests beyond the child (in) nature dualism? The primary goal is then to explicate the ways in which curious practice aids in highlighting the neglected properties of the mutual becoming of children and forests.

The philosophical and methodological approach evident in our framing of childrenforest with curious practice reflects emerging "posthumanist" (i.e., beyond humanist or human-centered) approaches to educational research (e.g., Snaza et.al., 2014) that partially converge with "sociomaterialism," "post-anthropocentrism," "new materialism," or "new empiricism." These perspectives are mobilized by theorists such as Barad ( 2007), Haraway ( 2008), Braidotti ( 2013), Bennett (2010), and Stengers (2011). At the core of these approaches is a focus on the relations between agential entities rather than on the individual (human) actors. This means that emphasis is on the shared processes through which relations take place rather than on individual (human) views of 
these relations. This theoretical insight helps to elaborate a basic premise of childhoodnature in which humans and their nonhuman surroundings do not exist independently of each other (Malone, 2015; Rautio, 2014; Snaza \& Weaver, 2015; Taylor, 2012).

Childrenforest is invoked as a living, throbbing, productive, open whole rather than composed of interacting (turn-taking), clearly discernible individuals. Childrenforest is a cumulative effect of the diversity of individuals labelled "children" and the multiplicity of things and beings called "forest." Childrenforest is an entanglement, a more-than-human entity that emerges unpredictably and cannot be planned in order to be known, especially through conventional methods of qualitative research. Our concern is, therefore, with exploring encounters of children and forest in terms of their emanating, but not palpable, assemblage, which nevertheless leaves traces and "speaks" with a researcher through unusual, interesting, and unexpected events. This is an approach to qualitative inquiry and to data that Svend Brinkmann ( 2014) calls abductive or breakdown driven, and Maggie MacLure (2013) characterizes as openness to surprises and to the mutuality of researcher and data reconstituting each other. Both challenge the idea that research is both planned ahead and executed accordingly and that data is simply collected; Brinkmann (p. 722) suggests that inquiry arises out of a surprising situation rather than in relation to collected data. Such openness to serendipity can generate new knowledge of what is significant in the relationships of children and forests through highlighting what has been missing from previous - well planned - studies and how, by approaching childrenforest, we can enrich the understanding of who we are as humans.

To study childrenforests as entanglements capable of surprising us, we apply curious practice as a methodological form of what is called multispecies inquiry or multispecies ethnography. The novel yet rapidly emerging approach of multispecies ethnography (Kirksey \& Helmreich, 2010) foregrounds all animals as embodied individuals sensing and making meaning of their environments and thus as legitimate participants in the ethnographies of shared lives (Buller, 2014). Multispecies ethnography thus focuses on human-animal coexistence in terms not only of what the individuals are (biologically) but what they do (biosocially) and not as beings but as becomings creating themselves together through action and interaction (see Ingold, 2013). In our study, the curiosity in curious practice reaches beyond animate beings - or rather questions the notion of "animate."

We begin by briefly reviewing the literature that explores children in forests. This will assist us in characterizing what has already been done methodologically in disclosing and representing the experiences of forests by children. On the surface, these studies do not seem to treat children and forests as categorically separate. But a closer reading shows that an underlying binary exists: children are often put in a dominant position of knowledge producers whose task is to experience forest (as if it is an object) and express it in a representational manner. Ultimately, these subjective representations are further used to improve learning objectives and are often presented as a portrayal of an objective reality.

We will then move to describing curious practice, as introduced by Donna Haraway and based on the work of Vinciane Despret. The relevance of our methodological choice and its location within a broader field of multispecies ethnography is discussed. In the section where we present our account of curious practice, we show that curious practice of childrenforest differs slightly from the curious practice described and performed by Despret. Despret's ( 2015) aspiration to make ontological claims about the potential "reality" of her research companions, or the "mystery manifestation"/"resolution of enigma" (p. 59), as she puts, is what we will leave out. For this and other reasons, we combine the methodological foundations of Despret's curious practice with Eduardo Kohn's ( $\underline{2013}$ ) "anthropology beyond human" in order to customize curious practice with respect to our research context, subject, and the participants. By thinking with Kohn, we attend to the ways of looking at childrenforest through the notion of "human and nonhuman semiotic selves" to go beyond mere symbolic 
representation inherent in humans. We also apply Andrew Pickering's ( $\underline{2013}, \underline{2017})$ concepts of decentered becoming and islands of stability to the encounters of children and forest to demonstrate the co-constitutive becoming of children and forest and the appearance of seemingly stable configurations within this becoming.

\section{Previous Literature}

Intellectual conditions for thinking beyond the "child" and "nature" dualism exist and have existed for a while (e.g., Russell, Sarick, \& Kenelly, 2002). Many authors contributing to this current handbook engage with the entangled childhoodnature rather than with childhood and nature separately in order to challenge the nature/culture divide implicitly present in much of (early) childhood and outdoor/environmental education research that we review below (see also Clarke \& Mcphie, 2014; Malone, 2015; Rautio, 2014). The following studies are dedicated to an investigation of children's experiences in the forest and mainly concern exploring the effect of forests on a child's well-being. For the purpose of relating and contrasting curious practice and childrenforest to these approaches, we will trace the methodological commitments of these studies and the level of the children's own contribution to the end result and formulation of new perspectives for the development of educational knowledge.

There is an evident trend, located at least in the Nordic or North European countries, of growing numbers of forest day-care centers, gardens, and schools. The reasons behind the upsurge of educational contexts close to nature are yet to be explored in detail, for instance, the parental choices that create the demand for such places (Borge, Nordhagen, \& Lie, 2003). There is no shortcoming of research emphasizing the positive influence of direct contacts with nature to children's well-being. Among these are overall health and motor fitness (Fjørtoft, 2001), linguistic development and concentration (Schäffer \& Kistemann, 2012), increased engagement and prosocial skills for children with special needs (Griebling, 2015), as well as growth of interest in forest life (Harris, 2015). Due to the prevailing developmental approaches to education, children's doings are often subjected to meanings ascribed by parents, educators, and other fellow adult citizens (e.g., Blaise, 2016; Burman, 2007). The forest school trend and its underlying justifications seem to be no exception. There are studies that seek to foreground children's views and experiences. These, as we will argue by introducing a few examples, are methodologically conventional in that they entail little flexibility and/or critical evaluation of research designs and so often fail to address what matters to children beyond adult-imposed categorizations.

Nicola D. Ridgers, Zoe R. Knowles, and Jo Sayers ( 2012 ) conducted a study of children's experiences of play in a forest school using a qualitative approach (pen profiles and verbatim quotations), which constituted a well-planned research project with an anticipated objective of methodological rigor to be demonstrated through trustworthiness, credibility, transferability, and dependability of data. The result was to be approved by all authors during a triangular consultation process. The authors, however, concluded that their research lacks depth without presenting children's own voices, though evaluated "not in the manner that would typically be expected" (p. 53). This statement indicates the researchers' frustration over the initial plan for data presentation, which led to their agreement on the introduction of "raw" narrative - the individual opinions of children - that does not require interpretation and should be presented in the language of the children themselves.

Magdalena Rudkowski ( 2015) explored children's experiences in the forest with the help of hermeneutic phenomenology and the Mosaic approach. Children were encouraged to express their sense of the forest through photography and drawings, bookmaking, and child-led tours as well as in 
casual conversations with a researcher that would reflect on the children's experiences. Rudkowski also conducted a pilot study before the actual empirical research so as to test "whether they [data collection tools] were effective in capturing the children's experience and of interest to the children themselves" (p. 42). Rudkowski mentioned that six children (other than the main participants) were "included" in the pilot study. Yet, their experiences were excluded from the discussion. By doing this, the researcher immediately reduced to a common denominator those children's interests, values, and personalities that were investigated in order to ensure the effectiveness of the research objectives. Division of a research project into concrete stages with limited periods for "productive" data collection, aspirations toward results, and silencing some of the voices will not, however, ensure what Rudkowski called "open-ended, malleable and versatile opportunities without the specific design and tailoring for young children" (p. 106(7)).

Anna Golden (2013) embarked upon exploring and making meaning of the forest with preschool children, whose task was to express their experiences and understanding of the natural world through various forms of representation: drawing, writing, photographing, clay, blocks, embroidery, and other tools. Golden highlighted the importance of looking at children's own ways of seeing the forest, their ability to reflect upon the landscapes and their favorite places in order for adults to better understand children's learning objectives based on their representations of the forest. The binary of (wild) nature and (agential) culture is evident throughout, for example, in phrases and quotes such as "wild space," "wildness," "model of the forest," "stewardship of the forest," and "the world outside them." While Golden's methodological approach is in line with the conventional way of doing a qualitative inquiry, we found intriguing the fact that an inquiry into the children's view of the forest included, as if protecting the children from the same forest, "countless changes of dry, mud-free clothes" (p. 125).

Most of the studies reviewed promote the well-being of children and their positive attitude to the forest, as well as increasing the time spent outdoors as part of formal education; these studies nevertheless belong to the perhaps unintentionally anthropocentric ones (Clarke \& Mcphie, 2014; Malone, 2015). Furthermore, most of these studies emphasize the importance of planning in research. Planning, and following a plan, indicates an approach where the researcher knows about the topic/participants beforehand and/or has a clear hypothesis to test. In contrast, when the researcher lets go of much of her preconceptions and is curious instead, the task of planning becomes harder if not impossible. Well-planned and dutifully followed studies rarely break free from what is already known. This is especially weighty if what is presented as known is a child.

Furthermore, presented studies are exceedingly attentive to a child's representation of forest. Focusing on meanings or explanations behind children's actions - be they adult imposed or the children's own - does not acknowledge the interdependence or relationality of childrenforest. Any single meaning or explanation is always only partial. Any symbolic representation of a child's interpretation of their movements is, therefore, limited only to human perception or cannot be interpreted at all. Alternatively, the focus in this chapter is on the co-constitutive processes that give rise to childrenforest. All of the actions, intentions, and intensities are the result of co-constitutive process of both children and forest. With such processes, it does not make sense to ask after meanings or explanations of only one kind of individual. Childrenforests emerge spontaneously: a child and a tree, for example, are drawn to each other in complexly relational situations where categories do not apply but where categories can be made. Curious practice shows us the ways of approaching these emergent categories, and with that, we proceed to the exploration of this methodology in the next few sections, where the processes of the childrenforests are discussed. 


\section{Curious Practice Unfolding}

Although the idea of being curious and having a sense of wonder in doing research is not a novel one (Daston \& Park, 1998; Evans \& Marr, 2006; MacLure, 2013; Stolberg, 2008), an approach of Vinciane Despret stands out among all the approaches, for it encourages researchers to work relentlessly with their curiosity, ask interesting questions, and immediately doubt them. What is most important, Despret does it not only and not so much for the sake of humanity as for the sake of morethan-humans.

Curiosity as a natural human ability for inquiry is commonly argued to be a desired trait in both teachers and students, scientists, and everyone who shares an idea of lifelong learning (Dewey, 1933; Schmitt \& Lahroodi, 2008; Stolberg, 2008). Frederick Schmitt and Reza Lahroodi ( 2008), for example, attach a higher epistemic value to curiosity than to a sense of wonder, stating that "In wonder we are not overridingly motivated to resolve cognitive conflict, while curiosity motivates us to inquire" (p. 132).

In other words, wonder does not necessarily imply a desire to know, when in fact curiosity does. In wonder, you might find something/somebody curious and appreciate its/her/his mystery without going further than that. This something or somebody usually stands in a position of novelty to an observer (Leask, 2002, p. 25), though it should not always be the case. Oftentimes, these two notions are used interchangeably as their borders are not clearly defined. Given the visible ambiguity of both terms and a definition of imagination presented further (see at the end of the current section), we suggest a notion of wondering curiously, based on our interpretation of Despret's (2014, 2015; Buchanan, Chrulew, \& Bussolini, 2015) works. For a researcher, to wonder curiously would mean to stimulate himself/herself to notice novel/interesting even in ordinary, learn to be surprised at it, and then, if given an opportunity, approach it by means of imagination.

What Patricia Williams (as cited in Gordon, 2008) refers to as the "vast networking of our society" (p. 19) and Avery Gordon ( 2008) calls a "complex personhood" summarizes the existing approach to curiosity, which pivots on the curiosity oriented toward complexities and intricacies of human society, whereas Despret teaches us to think both with humans and not. She urges us to build our nowadays very fragile relations "with and for earthly beings, living, dead, and yet to come" (Haraway, 2015, p. 5 ) as well as to recognize the risks and limitless possibilities of "wonder" within human-nonhuman encounters. There is no need to deny a historicity and a profound complexity of multiple nonhuman forms of life, which we, as humans, are nested in.

Vinciane Despret seeks fertile collaborations with people and animals through an art of visiting. For her visiting is a skill of resistance to grand narratives by means of co-creating new stories with more-than-humans. It is an ability to unplan research by turning it into a spontaneous journey rather than a data collection process. It is an art of "sniffing" an invitation to enter a territory of the other with a brief and polite visit. Donna Haraway ( 2015) further clarifies:

Visiting is not an easy practice; it demands the ability to find others actively interesting, even or especially others most people already claim to know all too completely, to ask questions that one's interlocutors truly find interesting, to cultivate the wild virtue of curiosity, to retune one's ability to sense and respond - and to do all this politely! (p. 5)

Curious practice or the polite way of visiting is about creating conditions for encounters. The kind of conditions a curious researcher is after are interesting and lively and of the kind that will lead to encounters without assuming that the other can be known. Rather than focusing on "rich data" production, the researcher is responsible for finding ways of listening, seeing, and being with others in the moment. Despret (2015) herself associates this practice with the word "respect" as a form of suspicion of one's own reasoning. The politeness of a researcher thus includes doubting the 
commonly accepted, human-centered approach to her nonhuman co-researchers. The researcher is responsible for approaching research in a way that will put herself in a position of resistance, in a way that will perplex things to the extent that new questions need to be asked, the kind of questions that matter for the nonhuman participants and co-researchers. One must talk to the others, listen to, be inspired by, and, eventually, tamed by them by virtue of, if not reaching, then coming closer to an understanding of what matters to other-than-humans.

Curious practice can be seen to be the heart of multispecies ethnography or multispecies inquiry attending to the hybridity, entanglement, and relationality of all entities and lively beings, humans included (Haraway, 2008, p. 330; Lorimer, 2007, p. 913), and thus dismantling the modern myth of the purified and separate realms of "nature" and "society" (Latour, 1994). For the purposes of the study described in this chapter, and as opposed to many studies in the field of childhood and nature, curious practice recognizes both children and nature as being entangled and relational co-researchers rather than objects of the study. It resists an intended dialogue being replaced with a prescriptive monologue; it focuses on the openness and availability of the researcher, rather than that of the participants. According to Despret ( 2015):

The ravens will literally recruit their researcher into what will become a passionate inquiry; they will reveal to him the resolution of an enigma the difficulty and the interest... In learning to recruit them, he learned to be recruited by them. That which constitutes achievement for a raven now constitutes, in another way, achievement for himself; feeding on their emotions, letting himself be pervaded by their joy, letting himself be drawn into their enigma: converting the environment into a little more of himself. (p. 59, 66)

In the study discussed, the children and the forest will recruit the researcher. And so, rather than trying to guide the hybrid and entangled childrenforests, the researcher becomes guided by them.

In order to be guided, the researcher has to admit to the necessity of being open to the yet unknown, to the possibilities of seeing differently. She has to learn how to be a not-yet participant of the potential assemblages of children and forest, to be within and yet observe from afar the childrenforest becomings. The monist overtones of such vocabulary imply freedom from the dualist worldview, the legacy of science. It is not even a matter of obligation, but an unconstrained, effortless, naturally occurring being and acquiring of another sort of vision, which Margaret McMillan ( 1904) referred to as seeing beyond human sight or attending to the higher structures of mind:

Half the difference between the discoverer and the ordinary man may be said to consist in this, that the former can see that which is invisible to the other. - He can conceive movements and forms that are beyond mere physical vision. (p. 168)

This type of vision, in accordance with Despret, is equivalent to imagination or the ability of a researcher to create multiple hypotheses, versions of the same event, which are hidden from an ordinary person behind often blunt and commonly accepted cause-effect relations (Buchanan et al., 2015). The task of the researcher is to imagine what is absent from the scene in order to create conditions for approaching something not yet revealed. Imagination in the current chapter is, therefore, defined as a tool to gratify one's curiosity, an immense power of humans to think in terms of possibilities, create, link, mix, divide, or separate ideas that might further explain an observed phenomena within given sensorial capacities (Hume, 1975). What is lost, however, in the process of representing the "data"/versions that might perform a quite functional duty is nonrepresentational. The affect (Deleuze \& Guattari, 1987) from the encounter of children/researchers and forest, emergence of childrenforests, is exactly what intensifies the moment and oftentimes liberates us from the meaningmaking. With that the researchers are often limited in their ability to imagine/see this sort of irrationality of unknown content and have to either "grope about in darkness" or find a way to go beyond a mere imagination (Holton, 2016, p. 915). Alternatively, as Despret (in Buchanan et al., 
2015) explains, the researcher has to learn "to trust the world" (p. 170) in order to be guided in darkness, meaning a human imagination is rather an extension of the thinking world that is alluding to the right questions and possible answers. We, as researchers, just need to sometimes acknowledge that irrational in our head might be an echo of ordinary, the gesture of a wondering other.

In the next section, we will discuss how to unplan research with the help of curious practice. We will exemplify this by going through how curious practice was employed theoretically and methodologically in the context of the study conducted at a nature school in the north of Finland.

\section{Customizing Curious Practice and Unplanning Research}

\section{Theoretical Synthesis}

The decision to unplan research might seem risky - as scholars we are educated first and foremost to avoid losing control. Yet, studies in which unpredictability and loss of control are taken as productive, if not virtues, are proliferating (e.g., Despret, 2014, 2015; MacLure, 2013; Rautio, 2014; Taylor \& Pacini-Ketchabaw, 2016). Affrica Taylor and Veronica Pacini-Ketchabaw ( 2016) point out that our encounters with other-than-humans are by nature unpredictable and, therefore, planning is not only impossible but even attempting to plan is often impractical. MacLure ( 2013) discusses the unexpectedness of wonder in the research process of data collection and its capacity to engage with us in a form of event that cannot be planned in advance. It may just happen, if we are lucky enough. In regard to this, Despret encourages researchers to avoid remaining passive in a hope of seeing/sensing wonder and rather amplify the chance of its occurrence. By amplification, Despret (in Buchanan et al., 2015) does not always mean planned actions. Instead, she indicates the ability of a researcher/an involved human to persist in proposing differing "gestures," to lure the other or rather respond to its subtle signals:

You don't improvise your own gestures, you just hope that making a gesture will provoke one of the responses you expect, and if not, it will be a response that will make the dancer respond. (p. 175)

To be able to address the emergence of childrenforest, we bring Eduardo Kohn's ( $\underline{2013}$ ) thinking to resonate with what has thus far been said about curious practice. Eduardo Kohn is an anthropologist, whose research attends to the questions of human nature mediated by the forest. $\mathrm{He}$ attempts to think with forests through people for whom a forest is more than a place of dwelling. Kohn invites us to reach beyond human thinking with the help of semiosis (the creation and interpretation of signs), and he draws mainly on the Charles Sanders Peirce's typology of signs. In order to understand how curious practice is applied to the relationality of children and forest, we need to obtain an image of how Kohn translates this typology into his study and what he suggests searching for.

The famous Peircean triadic model of signs stands for icons, indices, and symbols, whereby icons are "involving signs that share likenesses with the things they represent" (Kohn, 2013, p. 8); indices are the product of relations among icons, "they tell us something new about something not immediately present" (p. 52) or point out the as yet-inexperienced; and symbols are "the product of relations among indices" (p. 53), "distinctively human representational forms" (p. 8) and what makes human language possible. All these signs constitute a complex hierarchy of signs, where symbols are the products of and nested within indices and indices are the products of and nested within icons. They are not strictly delineated but rather flow into each other in the continuous chain of receptive 
relations. Indices need icons and symbols need indices, but not the other way around. Therefore, icons are the most basic signs that exist at the margins of semiosis, because iconicity makes it hard to notice the difference between two things. A brief example of the sign relations can be a moment when Niina showed a picture of a worm to children in the lesson called "Animals' food in the forest" and children replied that birds eat worms. The picture of a worm is the icon, a very close resemblance of what the object represents. Immediately this picture sparked among many children a reaction of disgust, because it pointed to the possibility of relations with this worm (holding it, being near), and it seems it is not a very pleasant experience for some. That reaction bears an indexical reference to the event not yet present. And only after Niina asked whose food it is, did the children reason that it was a bird's, because for them (humans) the picture of a worm became a symbol of a bird's food in the process of their education.

Icons and indices, being reals or manifestations of something material/immaterial (thoughts) that exist independently of humans are embodied in worldly "habits, regularities, patterns, relationality, future possibilities, and purposes" (Kohn, 2013, p. 59) and are "far more expansive and extensive than human consciousness and its languages" (Payne, 2016, p. 171). In other words, icons and indices are aligned with an evolutionary process during which they emerge and proliferate as a part of form, as reals, which we humans cannot always identify. Kohn's idea in his research of thinking behind the forest is to attend to those iconic and indexical signs that are often unnoticed or to go further than our only habit of symbolism in order to become available to those diverse habits, relations that extend far beyond humans. Kohn's ambition unites his research with that of Despret and methodologically echoes her idea of curious practice in many ways.

The unifying feature of Despret's and Kohn's methodological approaches is their aspiration to know beyond the human and, hence, a need to train oneself to cooperate, live, and sense with nonhumans. Both Despret and Kohn participate in observing nonhumans through and with humans, sometimes through their own experiences, or at times in the absence of humans (see Kohn, $\underline{2013}$, Chapter 5). Likewise, we hope to approach childrenforest through and with the help of children and forests, via creating opportunities for their emergent dance. Secondly, both Despret and Kohn deny the accuracy of causality of the world with relation to the way human beings perceive it: "We don't know outside causality how things connect together," Despret (in Buchanan et al., 2015, p. 176) says. Therefore, we shall abstain from looking exclusively at the connectivities of an event that our brains tend to create immediately and unquestionably. Finally, both researchers bring to the forefront the importance of being imaginative and being less bound by theories that colonized our minds. Kohn ( 2013) observed that "People in Ávila try to make sense of these various selves that inhabit the forest by trying to see how they see, and by imagining how different perspectives interact" (p. 96). He also very meticulously explored and imagined different versions of various phenomena. Similarly, Despret admits the partiality of cause and effect interpretations and encourages us to search for and to imagine links between events in unlikely ways, creating unimaginable connections that develop into a multiversion story.

Expanding imaginative abilities in the framework of the study discussed means that we do not take for granted even the most mundane events: a child making a snowball, for example (see Fig. 1). Our first instinct and the answer to the question "What is happening?" is to view a child making a snowball for the fun of it, perhaps to throw it. We then move to viewing how the event could be taken as a relationality of signs. The round shape of a snowball takes us to what Kohn (2013) refers to as a form, a pattern propagated by "configurations of constraint on possibility" (p. 157). This round shape evolved as a result of an interplay between a human hand of a special bone constitution that forms arches and snow that has specific sticky lumping properties. A natural human grab of the right kind of snow will produce a snowball of a fairly round shape. This, in its turn, means that a ball's round shape 
is irreducible to more basic forms and is the simplest in itself. The round shape of a snowball emerged because of human and nonhuman agencies. Snow with its recurrent properties emerged independent of humans, and its representational modalities support its functionality in this particular context. So to speak: "semiosis exists beyond human minds" (p. 159) and informs humans about itself through humans thinking about it. The child, for that reason, performs an action with snow not necessarily because he/she solely decided doing so but also because the thinking forest conveyed a message to be further substantialized. As Despret (in Buchanan et al., 2015) put it: "if we know what importance means, it's because a blackbird taught us" (p. 176). Similarly, Kohn ( $\underline{2013})$ instigates an idea: "...the fact that we can make the claim that forests think is in a strange way a product of the fact that forests think" (p. 22).

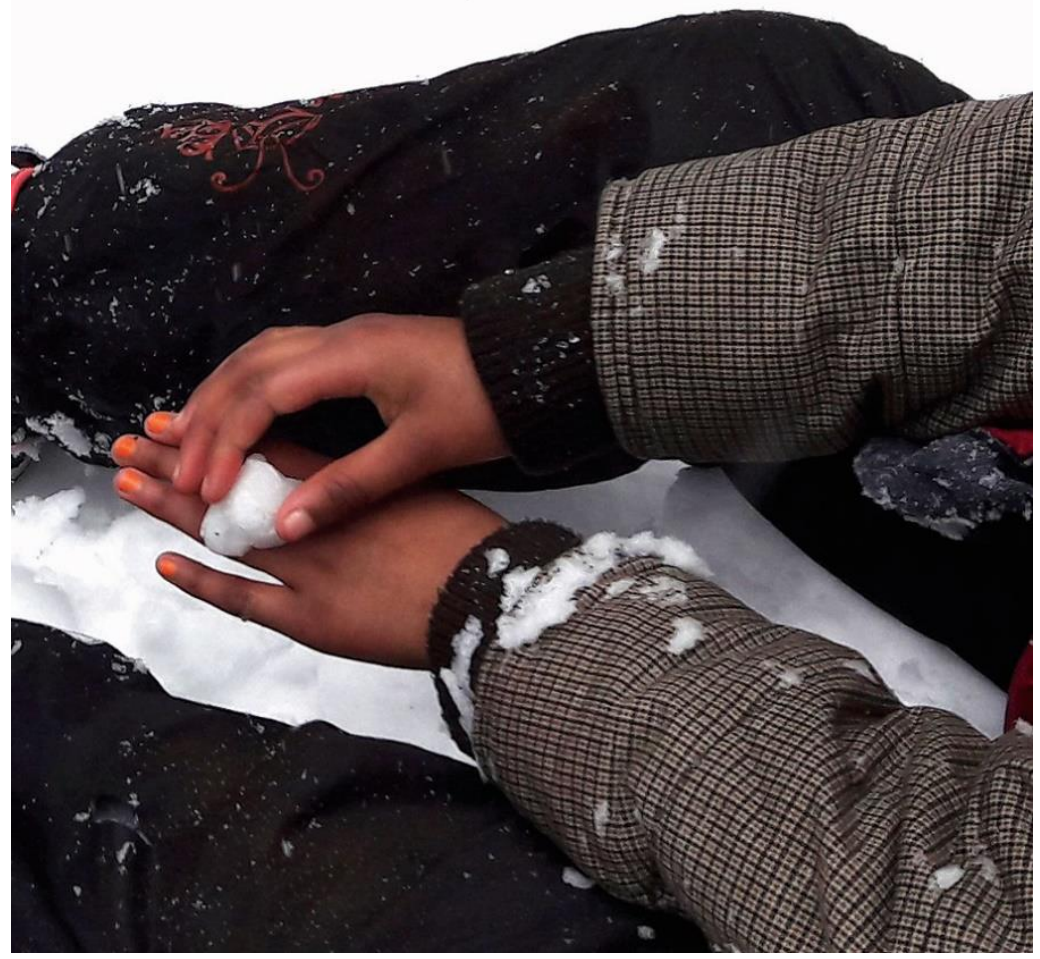

Fig. 1

Form. (Source: Authors' photograph)

Therefore, Despret and Kohn talk about imagination that is less shaped by human knowledge, dogmas, and common categories of thinking and more by the knowledge of other-than-humans. This type of imagination is peripheral, uncontrolled, or emergent and allows the researcher to visualize links within one event or between events otherwise. The opponents would argue, though, that imagination of this kind is a foe of impeccable science or falls within a certain themata, as Gerald Holton ( 1996) explains - "the often unconfessed or even unconscious basic presuppositions, preferences, and preconceptions that scientists may choose to adopt, even if not led to do so by the data or current theory" (p. 201). Eventually, there is a possibility that adherence to these convictions might lead to speculative conclusions and an academic fiasco. In spite of that, Holton recognizes undeviating need in scientific breakthroughs, which the thematic imagination, visual as well as other types of imagination might successfully fulfill, as they inspire to imagine unimaginable and "open up entirely new worlds" (p. 207).

On the other hand, the fundamental difference of Despret's (2014, 2015) and Kohn's ( 2013) methodological frameworks is in their research subjects. That is, Despret's interest is to investigate, reveal, and unearth animals' behavior which a human being has never been aware of before. Concurrently, Kohn delves into a more-than-human semiosis or, in particular, the thinking behind the 
forest. Both tasks are hard to tackle, and both of them require an enormous commitment in terms of attention, curiosity, self-critique or politeness, and of course time. Yet, observing, working, and thinking with animals are essentially distinct from thinking with the forest, which many living beings are part of. While Despret's idea is to propose many different gestures to the animals in the hope they would respond to these gestures, Kohn proposes to think in terms of patterns, habits, and regularities to approach the way the forest thinks. In both cases there is a chance that other-than-humans might make themselves knowable: animals through a new, interesting behavior and the forest through semiotic processes.

According to our account of curious practice, we, in line with Despret's research, show a plurality of childrenforests in the same manner as she tries to demonstrate to the world what makes "a plurality of singular animals" (Buchanan, 2015, p. 18), but therewith we acknowledge the ontological differences of our respective research subjects. We do not observe a behavior of childrenforest; we observe a communion of children and forest, their "becoming with" (Haraway, 2008) that reveals itself through patterns, generals (habits, regularities) (Kohn, 2013), traces, inclinations, and neglected confluences (see further). Among these, signs with indexical reference can also be classified as islands of stability (Pickering, 2013, 2017).

Andrew Pickering ( 2017) helps us to understand "islands of stability" as joint products of humans and nonhumans, "configurations, sociomaterial set-ups, where some sort of reliable regularity in our relations with nature is to be found" (p. 140). According to Pickering ( 2008 ) and to the philosophical orientation, labelled posthumanism, humans, and nonhumans "appear on the same plane as mutually constitutive of practice and as each irreducible to the other" (p. 292). Thus, all participants in the research are decentered and always already transformed in a decentered becoming. Neither children nor trees/animals/air/snow hold a position of priority. Everyone is transformed in the dances of agency (Pickering, 2013) or transmogrified by the worldly dynamic processes. The desire to find stability, albeit illusory, is inherent in humans and nonhumans as we are as all living organisms that seek for survival; thus, we are in need of structures, which, however, are still under the control of nature and its "unpredictable liveliness" (Pickering, 2017, p. 143). With that, we are still emerging with and are being transformed by the world; we are part of the worldly flux of matterings and becomings, in which islands of stability sustain the inevitable duality of people and things.

The idea of islands of stability can be extended to cover all living organisms that create these islands for self-protection. An example of such organisms could be antibiotic-resistant bacteria that undergo mutational adaptations or horizontal gene transfer (Munita \& Arias, 2016). While antibiotics can be considered an island of stability for a human, the changes in the bacteria's gene structure is an island of stability for bacteria or at another level called as endosemiotics. For us, in the study of childrenforest, the islands of stability are not only material constructs but also the impetuses and intentions leading to the emergence of these structures in the first place. With curious practice, we focus on the ways in which children and forests seek mutual stability. These ways can be intentions, facial expressions, movements and intensities, sounds, shadows, gazes, hints, or any minutiae unique in its transient being which could otherwise go unnoticed, undiscovered, and, most importantly, unremembered (Duhn, 2016). The presence of the teachers and the researchers in the forest can also be considered as an island of stability, as adult and nature relations form invisible structures of protection for children that allow them to feel relaxed and open to the engagement with forests. The task of a researcher is to think beyond these islands of stability, that is, to "see" their origins, to locate their embeddedness in each historical and sociocultural situation, and eventually to be able to argue for the significance of childrenforest.

Looking at the childrenforest becomings through the notions of islands of stability and decentered becoming helps us to see more clearly each and every sign, habit, or an emergent real that appears, 
exists, and grows through the chain of signs. Being indexical in their nature, islands of stability point to the fragility of life, which urged humans and nonhumans to create these islands in the first place. We ask why these islands appear, and what motivated their creation? This automatically lead us to a better understanding or guess about the potential in our respective context reals. With Vinciane Despret, we politely explore, imagine meanings otherwise, and create links between meanings in a hope to approach these reals that exist and proliferate in the world in the same form as they appear to the nonhumans. The element of "unplanning" is ingrained into the whole process of uncovering the routine: from unexpected and interesting encounters to wondering curiously and the interpretation/representing connections as a form. The occurrence of the "data" is as unpredictable as the questions/revelations about reals that come to the researcher during the childrenforest moment or later when the "data" lives its own life and never stay stable. These questions might appear in a dream or when we try to remember what was the dream about, in the laughter of children, or in the cry of gulls. We will be informed about these questions/connections and their importance by the messy entanglements (Pacini-Ketchabaw, 2013) or disrupted collaborations of the world.

To sum up, "curious practice" is an overarching concept that is primarily developed and applied in Despret's research but is also inherent in Kohn's studies. We have synthesized them by picking out the best in both. We have also applied a concept of islands of stability to help in theorizing about meanings and potential versions of the same event. Furthermore, we consider the concept of childrenforest as possessing some limitations in regard to the participants in the research, who are not only children and forest. Taking this into consideration, we do not pretend that a thorough investigation into childrenforest has been made, rather the point has been to create arguments for the significance of such a construct - beyond individual "child" and "forest." In what follows, the study grounding this chapter is presented and explained in detail.

\section{Empirical Application}

The nature school studied is a city-owned public institution in the service of local schools. Annually, up to 7,000 pupils visit the nature school - every day a new group of children arrives. In these circumstances, neither the nature school teacher nor the researchers can get acquainted with the kids let alone have a chance to build emotional bonds with them. However, some groups were familiar with the nature school teacher Niina from previous visits, and it made it easier for Anna as a researcher to be trusted, because Niina introduced Anna as her friend. Every day, Anna introduced herself in front of a new group and asked for permission to make pictures and videos, promising those pictures will not reveal personality, and headed to the forest.

Since, there is no one precise definition of what a forest is (Chazdon, Brancalion, \& Laestadius, 2010, we defined it in line with the research context; children's sensitivities toward invisible in the forest, such as folklore (Karhunkorva, 2005), media (Korhonen, 2008), and cultures in a given context (Goldman, 1998); objectives; and philosophical affiliation of posthumanism (that is beyond humanism) as:

a big living organism punctuated by human/nonhuman dwellings, human-made structures; engaged with climatic, political, geo-political, economic, sociocultural forces and flows; represented by multiplicity and variety of living and non-living organisms, both humans and more-than-humans, among which trees, mycorrhizal network and soil biodiversity outnumber the rest; a process of coconstitutive growth and development.

The context of Finland, its history, and culture, in addition to the northern location of the research city, perhaps, determine the myriads of ways children and forest engage. Forest is both people's home 
and temple. Home, nature, people, animals, peace, and unity are all synonyms of the forest. Such polysemy and accordingly complexity of human-nonhuman relationships attracted us to trace their significance with the help of curious practice. Intricacy and broadness of the definition, however, perplex the very notion of childrenforest, meaning that the current study attends to this phenomenon in a quite introductory manner. By defining the forest as an organism, we imply it possesses cumulative consciousness (Kohn, 2013; Reid \& Salonen, 2016). For this very reason, permission was also asked from the "three sisters" tree in the forest, adjoining the nature school, to conduct an unplanned study. Anna asked to allow wonders to reveal themselves for/in/with children. She asked to be a participant-observer of this revelation. And she apologized in advance for anything that might disturb this.

The role of Niina in the research cannot be underestimated and it was manifold. Mainly, she was doing her job by organizing forest trips and ensuring children were engaged with the forest through various activities. These activities were not always planned by Niina as she followed the enticement of the moment, the invitation to engage with something from the multiple learning supplies in her rucksack. From this perspective, she was a research partner who was creating, changing, trying multiple situations for children to engage with a forest otherwise, continuously using a "method alert to off-the-beaten-path practices" (Haraway, 2015, p. 6). The most interesting engagements between children and forest took place not during performing an activity proposed by the teacher Niina, but rather in between these activities, "on the move" or when children and forest had a chance to engage with each other through all the unruliness of the moment. Therefore, hospitable conditions in the spirit of Despret meant for Anna and Niina to be offering the circumstances for unstructured play and thus accepting the invitation of a forest to step on one of its paths without any prearrangement. This, we noticed, increased the chances of childrenforest emergence. Luckily, Niina sensed Anna's desire not to frighten away some interesting childrenforests, and she was often a rather careful observer who allowed children and forest to evolve into something else, unknown and unique.

In the following, Anna's journey into becoming a curious practice researcher is highlighted. Rather than a thought-out process with replicable and explicable how-to-do steps, this becoming was and necessarily is an intuitive process, more an attitude than an exact practice. In general, when methodologies are seen as situational, immanent, changing, and "becoming" (Deleuze \& Guattari, 1994), inquiry and research practices seem to draw scholars closer to singularity, open-endedness, and creativity. This is true of curious practice as well.

At the beginning of the research visits, Anna decided to simply experiment with what she holds, how she moves, or whether she speaks or is silent. She did not plan any of this but rather was ready to be changed by the moment. Oftentimes, it was air that brought about change. Her encounter with fresh air was a sort of impulse giving and guiding, telling her, mostly, to forget about taking notes. "It doesn't help," it says. To be in the moment with a hope to capture childrenforest demands maximum attention, inquisitiveness, and $360^{\circ}$ vision, if you like. Anna's goal at this stage was to concentrate on the performance, rather than interpretation, and on movements rather than thinking. By any means, she could not write in these circumstances. The number of humans and nonhumans participating in the research was big enough for her not to know anything about her co-researchers. Anna should not have and could not have anticipated the capacities, abilities, interests, intentions, desires, and movements of children and more-than-human entities. Being aware of causal relationships amidst some events, Anna was still "walking in darkness" not knowing and not controlling what can happen in the forest in the next few seconds.

One of the examples of childrenforests Anna had a chance to observe was a moment of childrenled play and their building figures out of snow during the forest trip. "What can be the most expected event?" one might think. Even a seemingly ordinary snowman is a unique construct each time it 
becomes made, a creation of both snow and a human being. Yet, children were not building snowmen/women. Figures unknown to her grew out of engagements between snow and children. Anna was just observing the process without interrupting in the hope of finding out what kind of marvel is revealed. At a certain point, she came closer. One boy stretched out on the ground to be further covered up with snow until only his face remained to be seen. His friends were adding snow handful after handful so that the boy's snow body was growing and evolving. Suddenly, friends built five strange small entities on top of the boysnow: they resembled a traditional snowman/woman in shape, yet their bodies were undone and did not conform to any particular rule. Finally, boys mounted a single branch on top of his head. Anna could not resist and asked what this was that they had created. They were unaware of what the whole structure was yet added that the branch was meant to be a horn. What Anna saw was an as yet unexplored snow-human-animal body born out of the childrenforest entanglement, nameless, but horned. At this point, she decided to halt any interpretations and preserved this event in a jar (S.Crinall, personal communication, February 2, 2017) (see meaning: to put all the data collected into an imaginary jar to open it in a while and see the data as a whole), to speak to it later.

"Later" came at the moment of writing this chapter. A desire to "open a jar" and focus on the fusion of data emerged spontaneously: the data tames the researcher and suggests the appropriate time for their mutual engagement. It may occur beyond the "original" context, and, rather, the shifting and fluid data creates new layered and fibrous contexts (Koro-Ljungberg, 2015). Thus, we consider that collaborations of children, forests, researchers, and teachers as well as the emergence of childrenforests might/can be multi- and/or acontextual (here: not essentially having meanings in one particular context). An open and curious researcher is rather a mediator between her research subjects and the audience, and not necessarily the one who controls this collaboration. Conversely, there are no childrenforests with certain experiences or understanding, because everything is entangled and we can only hope that this entanglement will guide us.

In an attempt to ask childrenforest the right questions, we subsume ourselves in thinking about this becoming as being nested in the broader semiotic processes happening in the forest with children, namely, as a part of a form. By looking at this event as a part of a form, we would like to refer to what Kohn calls a rhizomatic propagation of form (Kohn, 2013, p. 174). The boysnow emerged in a spontaneous rhizomatic process of co-constitution of children and snow. Children could not explain the meaning of the structure, because it was built by kids intuitively through following the patterned rhythm of the forest's thought. As Kohn would say, they were simply "listening" to the forest without necessarily realizing it, and that strange structure materialized as a product of co-constitutive power of living thoughts of both children and forest. Children were harnessing their exploratory freedom (Kohn, 2013) and thus were free from planning and meaning-making. At the same time, a snowboy creature evolved as both meaningful and without any special meaning. It evolved as an iconic manifestation of emergent real and effortless propagation of form, basic in itself and always unique.

Furthermore, these snow elements serve as a point of departure for us to be viewing them also as islands of stability for they emerged as more or less reliable structures/as non-living forms/as a product of constraints on possibilities that humans can identify with. It seems that, by having a touch of regularity in the unexplained, unrecognized, and nameless, children can escape the continuous turbulence of a dynamic world and stay impervious to this suspense while still being a part of it. Rather than perceiving childrenforest entanglements only as a romanticized version of children being in the forest, "children enjoying nature," and children uniting with nature, we suggest that childrenforests are multiple short-lived events. Childrenforests are both moments of boundless unity with all and moment of temporary categories - islands of stability. 
Anna heard children exclaiming: "It is so much fun!" A particular kind of experience is embodied in this word "fun": it is something that matters to the children and to the forest, something that is of importance in their co-constitution. Our (human) modes of representation often fail in addressing how something matters. Our intentions of not to elicit or investigate the reasons behind the boysnow rested on the decision to avoid making meaning but rather focus on how things matter.

There are epistemic challenges in understanding languages we do not speak, namely, a language of both children (Murris, 2013) and forest. It can also be questioned whether children themselves can describe with words a moment that mattered, the mattering that appeared as quickly as it disappeared (Koro-Ljungberg, 2013). To demand of children to characterize what has just happened is also to deprive childrenforest of its fleeting beauty, of its elusive and short-lived exceptionality, and of its curiosity in itself. To characterize these events is similar to reading words that consist of native and foreign letters:

\section{Gสวд ดอ $\mathbf{r}$ เช}

This phrase would not make sense to an unaware reader.

And while we can see these letters, childrenforests on the other hand are not so obvious to an eyesight. Without aiming at oversimplification, this (see Fig. 2) might be an accessible example of how childrenforest felt:

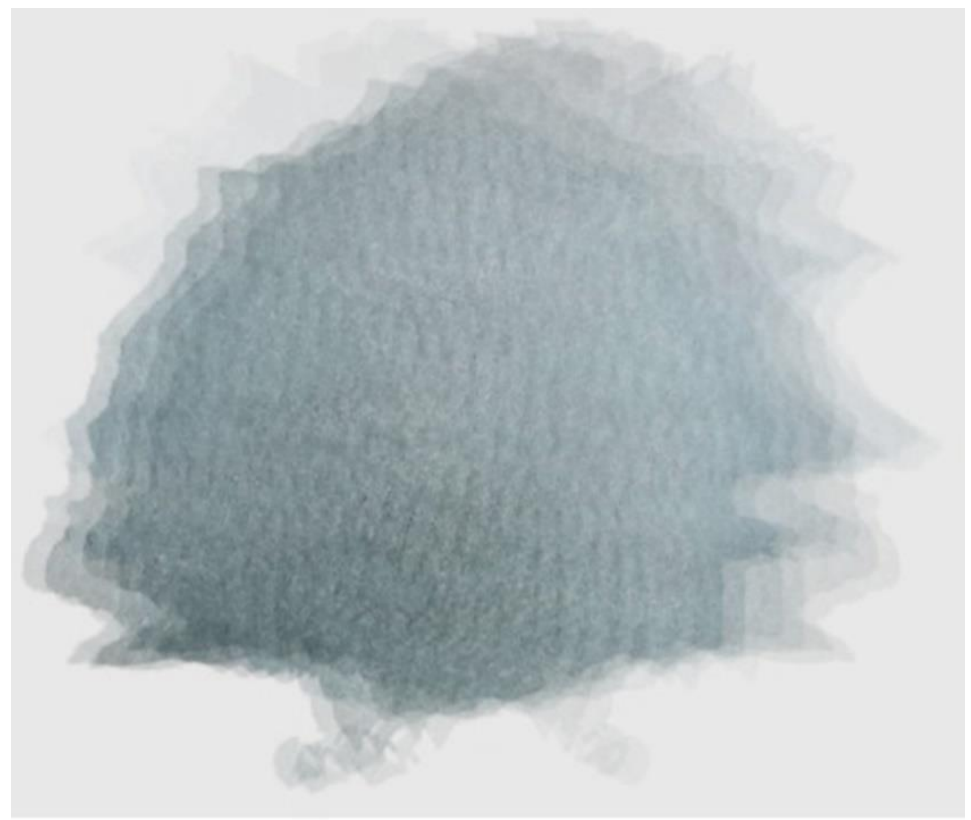

Fig. 2

Mattering. (Source: Authors' photograph)

Can we characterize this type of mattering, the essence of it, if any? Can we think of the appropriate words to approximate the meaning of the childrenforest entanglements? Pickering ( 2013) urges us to decenter the "words, language, symbols, representations, science" (p. 80) and imagine another type of science, one "of experimenting directly in, and learning from, dances of agency, instead of conjuring them away via some epistemological sleight of hand" (p. 81). And, as in curious practice, in science, we shall impugn our judgements, assertions, and unquestionable verities with reference to the other and remind ourselves of the emergent and (ir)regular in its uniqueness, continuously changing, growing, and developing.

Movements of children inseparable from forest leave traces. The examples of such traces from our research visits were the body of the boysnow, telling us that something has happened right here between snow and a child; a snow angel with a print left from a jacket; the smile of a child, who adds more snow to the growing snow entity; the roar of a child happy in a moment; frozen toes and fingers; 
a moan of hunger after an active play; a plucked plant thrown on the ground; a howl of the femaleimagined werewolves, protecting their kennel; hands smelling of mushrooms; a fir cone in a pocket; the message "Hello" written with a branch; a broken icicle a moment ago being a scepter; the echo of a song in the forest; pictures, memories, the emerged names of new creatures, and wet socks; and snow ricocheting off the shoes, to mention but a few.

Apart from traces visible, heard and observed by most of the participants, yet still taken-forgranted, curious practice allows us to focus on something that is not instantly useful or meaningful but simply intriguing. In particular, it enables us to start noticing the hardly-observed inclinations and neglected confluences. Inclinations are the sort of movements and intensities, depicted in a snapshot, where the child and forest act upon each other, incline to one another, reach out, tend, and desire for the childrenforest entanglement. It is similar to seeing an action in slow motion, depicting a spontaneous and momentary event. In one of the images, a girl is pictured falling onto snow with the intention of making a snow angel (see Fig. $\underline{3}$ ). While the snow angel is a trace or here a symbol, the falling girl and the as yet untouched snow, which in a second will become something else, are an inclination. We also believe that inclinations are entanglements in themselves, by which a girl and snow are always already intra-acting. It is a moment when clearly something happens in between, and we as researchers can use this opportunity to attend to this entanglement in case it is noticed. Snowballs hanging in the air, levitating children, hands reaching out to a dog, the dog's friendly sniffing in a direction of a child, leaning bodies, a snowflake falling but not yet reaching the cheek, a tongue trying to catch a snowflake, snow piles lying on the boughs asking to be shaken off, and oftentimes hands stretching to these snow piles.

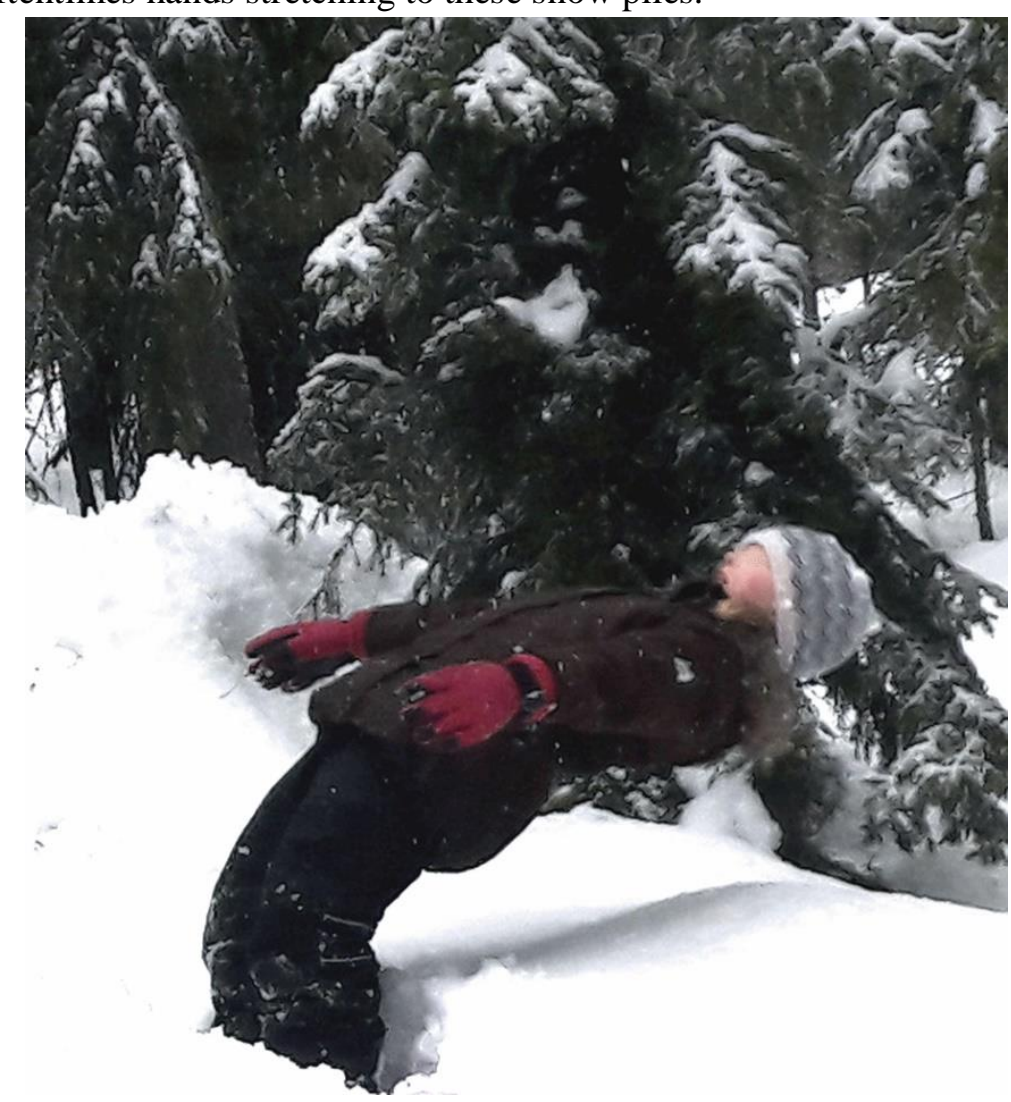

Fig. 3

Inclination. (Source: Authors' photograph)

And while inclinations happen intentionally, neglected confluences are unthought spontaneous fugitive moments of the bonding of humans and nonhumans that usually pass unnoticed, and no human, except for the observer, is actually aware of their existence (see Fig. 4). Neglected 
confluences are also islands of stability but, and according to its name, often overlooked. An island of stability in our understanding is every seemingly stable configuration resulting from children-forest relations, somehow substantiated/delineated in a world of dynamic transformations. An example of neglected confluence is a pine needle hooked on a hat; a hair accidently left on a tree; a shadow with a symbolic representation formed in an assemblage of children and forest; a snow castle, built by everyone, but accidentally in the shape of a heart, the fact of which was left unnoticed; the stripy patterns of a boy's jacket and the bark of a birch tree that the boy leaned on; and children reflected in a drop of melted snow slithering down the bark of a pine.

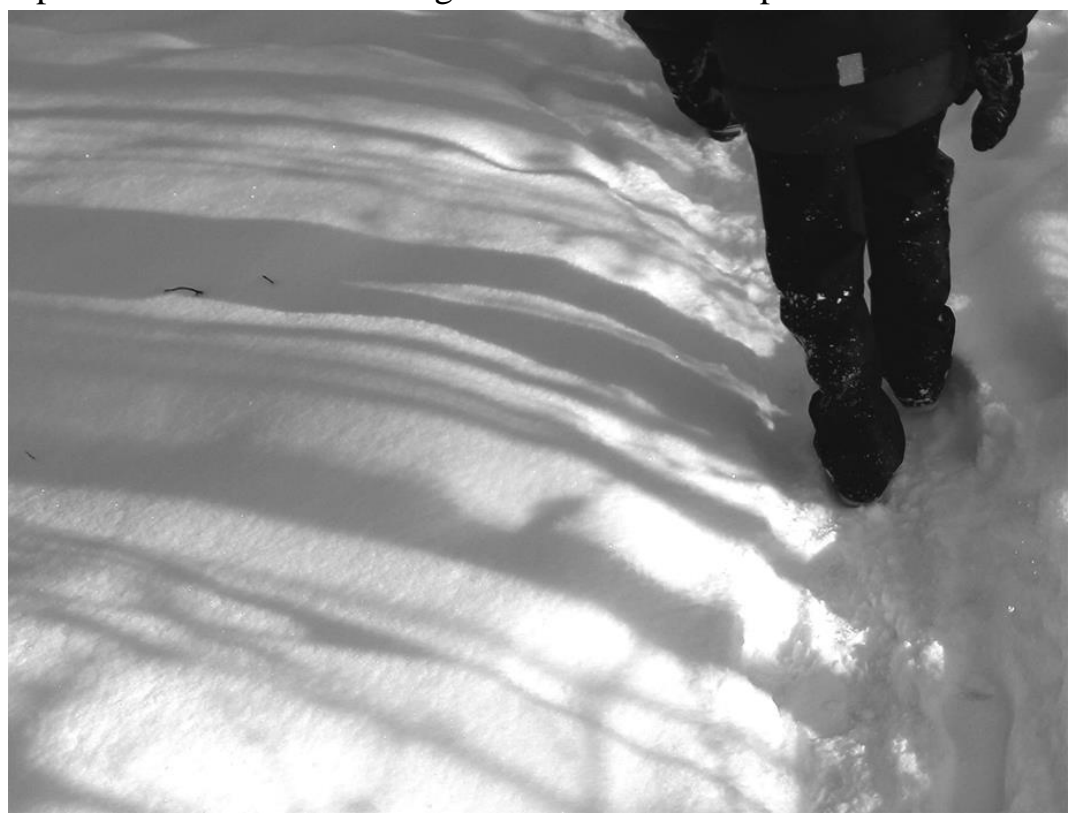

Fig. 4

Confluence "In line with the tree shadows." (Source: Authors' photograph)

Kohn ( 2013), while pointing out the intentionality of the processes happening beyond human (p. 91), did not mention unintentionality. The accidental moments (such as neglected confluences) that are often overlooked are also semantic and produced by the camera of a smartphone. The smartphone is a participant of the semiosis as it triggers meanings. The images in this chapter, which we could designate as "intellectual photography," resulted both from human and nonhuman intelligence and, as Kohn put it, refer to various images in his book, including photographs: "these images amplify, and thus render apparent, something about the human via that which lies beyond the human" (p. 222). Likewise, Jamie Lorimer ( 2010) when examining moving imagery for approaching nonrepresentational dimensions of more-than-human life asserts that moving imagery opens "thinking spaces for an affective micropolitics of curiosity in which we remain unsure as to what bodies and images might yet become" (p. 252). We argue that photography in this chapter that depicted a moment in slow motion is also a sort of moving imagery, which allows our imagination to extend and grow a number of propagating becomings, which we are not aware of yet - all essential characteristics of curious practice.

We have approached the enigma of childrenforest - of the co-constitution of children and forests by seeking to be tamed by children and the forest and by politely attending to their gestures and invitations. The ethical grounds of human-nonhuman encounters presuppose that we (humans) do not intrude or rather that we are limited in how far we might go. Slavoj Žižek (in Žižek, Reinhard, \& Santner, 2013) exemplifies it while discussing the ethics and politics of neighborhood:

I will never be able to account for myself in front of the Other, because I am already nontransparent to myself, and I will never get from the Other a full answer to 'who are you?' because the 
Other is a mystery also for him/herself. To recognise the Other is thus not primarily or ultimately to recognize the Other in a certain well-defined capacity [...], but to recognise you in the abyss of your very impenetrability and opacity. This mutual recognition of limitation thus opens up a space of sociality that is the solidarity of the vulnerable. (pp. 138-139)

What Žižek ascribes to interhuman relationships here can be applied to human-nonhuman relations, because human morality is nested within a broader concept of value, which is inherent in all living selves, both human and not. Value, thus, defines what is good or bad for a kind that aims at survival and subsequently flourishes on this planet (Haraway, 2008; Kohn, 2013). Therefore, and what Kohn reasonably noticed, "the goal is to be able to communicate across the boundaries that separate kinds without destabilizing them" (p. 144), and to that end, "politely" as Despret (in Buchanan et al., 2015) would say.

The ultimate purpose of this "communication" is to allow "the logics of life beyond the human to work their ways through us" (Kohn, 2013, p. 225), so that, with the help of other-than-humans, we could think beyond a human-constructed morality and strive toward a better world, the one with a little less evil for every living organism. It is noteworthy that neither Despret nor Kohn cultivate the idea of a perfect world, where cruelty and violence per se would cease to exist. However, Despret (as cited in Buchanan, 2015) imagines a world where people would neither hide behind a mask of innocence nor claim that a lack of innocence permits them to go beyond limits. In this world people would share a responsibility of hearing others after asking right/different questions. This idea eventually informs us what the environmental education is all about.

\section{Conclusion}

In this chapter we have discussed and described curious practice as an approach or methodology through highlighting the use of it in an empirical study. The methodological hallmarks of curious practice are underplanning, polite visiting, and responding to invitations. This means that the approach challenges any preconceived ideas or categorizations of the topics or participants in the study, making way for unanticipated arrangements and allowing attention to focus on what matters momentarily, rather than insisting on research being a meaning-making endeavor. What we have called childrenforests in this chapter are ongoing and open-ended processes of co-constitution and reciprocity. Childrenforests appear and disappear and often stay unnoticed. They came into existence in this chapter because we applied curious practice in our research of children's relations with forests: curious practice re-tangled and diversified the categories of "child" and "forest." And moments of childrenforests, temporary co-constitutions or islands of stability, were formed as result. The purpose was not to investigate children's experiences but to define ways in which curious practice allows the neglected properties of the mutual becoming of children and forests to be seen, appreciated, and contemplated under the terms and conditions of both children and forests.

Methodologically, this chapter has outlined a flat, situational, uncertain, and critical approach to researched phenomena which are complex, unpredictable, nonlinear, and involving human-nonhuman intra-action (Fenwick, Edwards, \& Sawchuck, 2011; Lenz Taguchi, 2011). Theoretically and empirically/practically, this calls for future studies in which curious, intuitive inquiry, situational living, and methodological encounters cannot be copied or uncritically reproduced. What follows will be diverse and unpredictable multiplications of methodological practices. These will be no doubt hard to control but nevertheless needed as they will provide new ways to "practice what we preach": to approach educational phenomena as inherently complex and mostly unpredictable. 
Despret's curious practice aided us in establishing a framework of uncertainty with multiple possibilities of communication through the art of polite visiting. It informed expansion of the "limen" of our imagination and seeing beyond the normative. Every time during the trips in the forest with children, we abstained from noticing only what our eyes can see; we tried to observe the not easily observable without trying to interpret. Later, though, the meanings were created as we tried to imagine a bigger picture of what was happening in the moment. Kohn's anthropology beyond the human provided us with a more practical framework of searching for signs that will keep the engagement across kinds open, inspirational, respectfully indifferent, but thoughtful. Likewise, Pickering's idea of islands of stability assisted us in making suggestions about possible intersections of human-nonhuman agency and how those are signs-generative. We, therefore, argued for the impracticality of the planning the empirical phase, which is always unpredictable when we work with children and forest, the momentous emergence of childrenforest.

As researchers and teachers, our calling is to better address the lived experiences of children in ways that help us to facilitate a more just future for all. To be able to break unhelpful patterns of knowing for and about children, we need methodologies that make it difficult to know or to plan, methodologies that require us to just experiment, be attentive, be lost and confused, and be always open. We are trained either to neglect ordinary moments as insignificant or to quickly interpret and turn them into profitable meanings. Ordinary moments can contain momentums for surprise, however. Attending to them might bring us closer to what really matters to our children, students, and human and nonhuman co-researchers and how this significance is likely to be born. We need to retrain ourselves to learn from nonhumans and ask interesting questions to understand their way of thinking.

The questions to be further asked are as follows: How do various discourses and interests potentially change/impact childrenforests? What is the role of curious practice in guiding these discourses? What are the ways curious practice is utilized/adapted in a variety of contexts? Apart from ethological studies, childhood and environmental research, curious practice is to be applied in any kind of inquiry that exists at the margins of an unknown, where difficult questions arise and where it is hard to speak about unspeakable, where no shared framework applies to a human being and her coresearchers, which would instantly guide them into the "likely-to-happen" kind of thinking, and where the researcher might be allowed not only to look at but also to respond. The examples of such research spaces are studies on death, historical geography, feral childhood, and spiritual and powerful traumatic experiences to mention but a few.

\section{References}

Barad, K. (2007). Meeting the universe halfway: Quantum physics and the entanglement of matter and meaning. Durham, UK: Duke University Press.

CrossRef

Bennett, J. (2010). Vibrant matter: A political ecology of things. Durham, UK: Duke University Press.

Blaise, M. (2016). Fabricated childhoods: Uncanny encounters with the more-than-human. Discourse: Studies in the Cultural Politics of Education, 37(5), 617-626. https://doi.org/10.1080/01596306.2015. 1075697.

CrossRef 
Borge, A. I. H., Nordhagen, R., \& Lie, K. K. (2003). Children in the environment: Forest day-care centers: Modern day care with historical antecedents. History of the Family, 8(4), 605. https://doi.org/ 10.1016/j.hisfam.2003.04.001.

CrossRef

Braidotti, R. (2013). The posthuman. Cambridge, UK: Polity Press.

Brinkmann, S. (2014). Doing without data. Qualitative Inquiry, 20(6), 720-725.

CrossRef

Buchanan, B. (2015). The metamorphoses of Vinciane Despret. Angelaki, 20(2), 17-32. https://doi. org/10.1080/0969725X.2015.1039818.

CrossRef

Buchanan, B., Chrulew, M., \& Bussolini, J. (2015). On asking the right questions. Angelaki, 20(2), 165-178. https://doi.org/10.1080/0969725X.2015.1039821.

CrossRef

Buller, H. (2014). Animal geographies I. Progress in Human Geography, 38(2), 308-318. https://doi. org/10.1177/0309132513479295.

CrossRef

Burman, E. (2007). Deconstructing developmental psychology (Paperback 2nd ed.). New York, NY: Routledge.

Chazdon, R. L., Brancalion, P. H. S., Laestadius, L., et al. (2016). When is a forest a forest? Forest concepts and definitions in the era of forest and landscape restoration. Ambio, 45(5), 538-550.

CrossRef

Clarke, D. A. G., \& Mcphie, J. (2014). Becoming animate in education: Immanent materiality and outdoor learning for sustainability. Journal of Adventure Education and Outdoor Learning, 14(3), 198-216.

CrossRef

Daston, L., \& Park, K. (1998). Wonders and the order of nature (pp. 1150-1750). New York, NY/Cambridge, MA: Zone Books; Distributed by the MIT Press. 
Deleuze, G., \& Guattari, F. (1987). A thousand plateaus: Capitalism and schizophrenia (B. Massumi, Trans.). Minneapolis, MN: University of Minnesota Press.

Deleuze, G., \& Guattari, F. (1994). What is philosophy? (H. Tomlinson, \& G. Burchell, Trans.). New York: Columbia University Press.

Despret, V. (2014). Domesticating practices: The case of Arabian babblers. In G. Marvin \& S. McHugh (Eds.), Routledge handbook of human-animal studies (pp. 23-38). New York, NY:

Routledge.

Despret, V. (2015). The enigma of the raven. Angelaki, 20(2), 57-72.

CrossRef

Dewey, J. (1933). How we think: A restatement of the relation of reflective thinking to the educative process (Vol. 8). Boston, MA: D.C. Heath \& Co Publishers. Southern Illinois Up, 1986/2008.

Duhn, I. (2016). Speculating on childhood and time, with Michael Ende's Momo (1973).

Contemporary Issues in Early Childhood, 17(4), 377-386. https://doi.org/10.1177/

1463949116677922.

CrossRef

Evans, R. J. W., \& Marr, A. (Eds.). (2006). Curiosity and wonder from the renaissance to the enlightenment. Aldershot, UK: Ashgate Press.

Fenwick, T., Edwards, R., \& Sawchuck, P. (2011). Emerging approaches to educational research: Tracing the sociomaterial. New York, NY: Routledge.

Fjørtoft, I. (2001). The natural environment as a playground for children: The impact of outdoor play activities in pre-primary school children. Early Childhood Education Journal, 29(2), 111-117.

CrossRef

Golden, A. (2013). Preschool children explore the forest - the power of wild places in childhood. In D. R. Meier \& S. Sisk-Hilton (Eds.), Nature education with young children: Integrating inquiry and practice (pp. 123-136). Florence, Italy: Routledge. 
Goldman, L. (1998). Child's play: Myth, mimesis and make-believe. New York, NY: Berg Publishers.

Gordon, A. F. (2008). Ghostly matters: Haunting and the sociological imagination. Minneapolis, MN: University of Minnesota Press.

Griebling, S. (2015). "Trees and things that live in trees": Three children with special needs experience the project approach. Early Childhood Research \& Practice, 17(1). Retrieved 10 April 2017 from http://ecrp.uiuc.edu/v17n1/griebling.html.

Haraway, D. (2008). When species meet. Minneapolis, MN: University of Minnesota Press.

Haraway, D. (2015). A curious practice. Angelaki, 20(2), 5-14. https://doi.org/10.1080/0969725X. 2015.1039817.

CrossRef

Harris, F. (2015). The nature of learning at forest school: Practitioners' perspectives. Education, 3(13), 1-20. https://doi.org/10.1080/03004279.2015.1078833.

CrossRef

Holton, G. (1996). On the art of scientific imagination. Daedalus, 125(2), 183-208. Retrieved from http://www.jstor.org/stable/20013446.

Holton, G. (2016). Our puzzling universe: From a promising beginning to forbidden knowledge. Social Research, 83(4), 905-916.

Hume, D. (1975). In L. A. Selby-Bigge \& P. H. Nidditch (Eds.), Enquiries concerning human understanding and concerning principles of morals. Oxford, UK: Oxford University Press. (Original work published 1751, 1777).

CrossRef

Ingold, T. (2013). Making: Anthropology, archaeology, art and architecture. Oxon, UK: Routledge.

Karhunkorva, R. (2005). "Kuulin metsän tarinan": kulttuurisesti ymmärretyn metsän merkitykset kuudesluokkalaisten Olipa kerran metsä-kirjoituksissa. ["I heard the story of the forest": Culturally 
understood meanings of the forest in the six-graders' "Once upon a time there was a forest" scripts]. Jyväskylä, Finland: Jyväskylä University Digital Archive.

Kirksey, S. E., \& Helmreich, S. (2010). The emergence of multispecies ethnography. Cultural Anthropology, 25(4), 545-576. https://doi.org/10.1111/j.1548-1360.2010.01069.x.

CrossRef

Kohn, E. (2013). How forests think: Toward an anthropology beyond the human. Berkeley, CA: University of California Press.

CrossRef

Korhonen, P. (2008) . Lasten TV-ohjelmiin liittyvät pelot, painajaisunet ja pelonhallinta. [Children's TV-included fears, nightmares, and coping with fears] (Acta Universitatis Tamperensis, Vol. 1332) Tampere, Finland: University of Tampere.

Koro-Ljungberg, M. (2013). "Data" as vital illusion. Cultural Studies $\leftrightarrow$ Critical Methodologies, 13(4), 274-278. https://doi.org/10.1177/1532708613487873.

CrossRef

Koro-Ljungberg, M. (2015). Reconceptualizing qualitative research: Methodologies without methodology. Los Angeles, CA: SAGE.

Latour, B. (1994). Pragmatogonies. American Behavioral Scientist, 37(6), 791-808. https://doi.org/10. 1177/0002764294037006006.

CrossRef

Leask, N. (2002). Curiosity and the aesthetics of travel-writing, 1770-1840: 'From an antique land': From an antique land'. Oxford, UK: Oxford University Press.

Lenz Taguchi, H. (2011). Investigating learning, participation and becoming in early childhood practices with a relational materialist approach. Global Studies of Childhood, 1(1), 36-49.

CrossRef

Lorimer, J. (2007). Nonhuman charisma. Environment and planning D. Society and Space, 25(5), 911-932. 
Lorimer, J. (2010). Moving image methodologies for more-than-human geographies. Cultural Geographies, 17(2), 237-258.

CrossRef

MacLure, M. (2013). The wonder of data. Cultural Studies $\leftrightarrow$ Critical Methodologies, 13(4), 228232. https://doi.org/10.1177/1532708613487863.

CrossRef

Malone, K. (2015). Theorizing a child-dog encounter in the slums of La Paz using post-humanistic approaches in order to disrupt universalisms in current 'child in nature' debates. Children's Geographies, 14(4), 390-407.

CrossRef

McMillan, M. (1904). Education through the imagination. S. Sonnenschein \& Co., Lim. Retrieved from: https://archive.org/details/educationthroug01 mcmigoog.

Munita, J. M., \& Arias, C. A. (2016). Mechanisms of antibiotic resistance. Microbiology Spectrum, 4(2). https://doi.org/10.1128/microbiolspec.VMBF-0016-2015.

Murris, K. (2013). The epistemic challenge of hearing child's voice. Studies in Philosophy and Education, 32(3), 245-259.

CrossRef

Pacini-Ketchabaw, V. (2013). Frictions in Forest Pedagogies: Common Worlds in Settler Colonial Spaces. Global Studies of Childhood, 3(4), pp. 355-365.

CrossRef

Payne, P. G. (2016). What next? Post-critical materialisms in environmental education. The Journal of Environmental Education, 47(2), 169-178.

CrossRef

Pickering, A. (2008). Culture: Science studies and technoscience. In T. Bennett \& J. Frow (Eds.), The SAGE handbook of cultural analysis (pp. 291-310). Thousand Oaks, CA: Sage.

CrossRef

Pickering, A. (2013). Being in an environment: A performative perspective. Natures Sciences Sociétés, 1(21), 77-83. https://doi.org/10.1051/nss/2013067. 
CrossRef

Pickering, A. (2017). The ontological turn: Taking different worlds seriously. Social Analysis, 61(2), 134-150.

CrossRef

Rautio, P. (2014). Mingling and imitating in producing spaces for knowing and being: Insights from a Finnish study of child-matter intra-action. Childhood, 21(4), 461-474.

CrossRef

Reid, L., \& Salonen, E., curators. (2016). Thinking like a forest. Retrieved 26 Feb 2017, from http:// laurenkreid.com/Thinking-like-a-forest.

Ridgers, N. D., Knowles, Z. R., \& Sayers, J. (2012). Encouraging play in the natural environment: A child-focused case study of forest school. Children's Geographies, 10(1), 49-65. https://doi.org/10. 1080/14733285.2011.638176.

CrossRef

Rudkowski, M. (2015). The complexity of understanding: Young children's experiences in a forest program (Doctoral dissertation). Retrieved from SFU Summit institutional repository (Identifier: etd9305).

Russell, C. L., Sarick, T., \& Kenelly, J. (2002). Queering environmental education. Canadian Journal of Environmental Education, 7(1), 54-66.

Schäffer, S. D., \& Kistemann, T. (2012). German forest kindergartens: Healthy childcare under the leafy canopy. Children, Youth and Environments, 22(1), 270-279. https://doi.org/10.7721/ chilyoutenvi.22.1.0270.

CrossRef

Schmitt, F. F., \& Lahroodi, R. (2008). The epistemic value of curiosity. Educational Theory, 58(2), 125-148. https://doi.org/10.1111/j.1741-5446.2008.00281.x.

CrossRef

Snaza, N., Appelbaum, P., Bayne, S., Carlson, D., Morris, M., Rotas, N., ... Weaver, J. (2014). Toward a posthumanist education. Journal of Curriculum Theorizing, 30(2), 39-55. 
Snaza, N., \& Weaver, J. A. (Eds.). (2015). Posthumanism and educational research. New York, NY: Routledge.

Stengers, I. (2011). Cosmopolitics II (R. Bononno, Trans.). Minneapolis, MN: University of Minnesota Press.

Stolberg, T. L. (2008). W(h)ither the sense of wonder of pre-service primary teachers' when teaching science?: A preliminary study of their personal experiences. Teaching and Teacher Education, 24(8), 1958-1964. https://doi-org.libproxy.helsinki.fi/10.1016/j.tate.2008.05.005.

CrossRef

Taylor, A., \& Pacini-Ketchabaw, V. (2016). Kids, raccoons, and roos: Awkward encounters and mixed affects. Children's Geographies, 15(2), 131-145. https://doi.org/10.1080/14733285.2016. 1199849.

CrossRef

Taylor, N. (2012). Animals, mess, method: Post-humanism, sociology and animal studies. In L. Birke \& J. Hockenhull (Eds.), Crossing boundaries. Investigating human-animal relationships (pp. 37-50). Leiden, The Netherlands: Brill.

Žižek, S., Reinhard, K., \& Santner, E. L. (2013). The neighbor: Three inquiries in political theology, with a new preface (TRIOS) (2nd ed.). Chicago, IL: University of Chicago Press.

CrossRef 